\title{
Profile Analysis of Students' Problem Solving Ability in Learning Biology in Surakarta State High School
}

\author{
${ }^{1 s t}$ Cahaya Fatima Harahap \\ Faculty of Teacher and Training and \\ Education \\ Sebelas Maret University \\ Surakarta, Indoneia \\ cahayademas@gmail.com
}

\author{
${ }^{2 n d}$ Prof. Dr. Ashadi \\ Faculty of Teacher and Training and \\ Education \\ Sebelas Maret University \\ Surakarta, Indoneia \\ Ashadiuns2014@gmail.com
}

\author{
${ }^{3 r d}$ Puguh Karyanto, S.Si, M.Si, Ph.D \\ Faculty of Teacher and Training and \\ Education \\ Sebelas Maret University \\ Surakarta, Indoneia \\ karyarina@yahoo.com
}

\begin{abstract}
This study was aimed to analyze the problem solving ability of high school students in biology learning. The method used was descriptive-quantitative. Data collection techniques used was problem solving essay test. The subjects were high school students grade XI in Surakarta which are divided into A category (high class) and B category (low grade). Based on the analysis, it can be known that the achievement of problem solving abilities in grade XI, A category includes: define the problem $(41.67 \%)$, examine the problem $(40 \%)$, plan the solutions $(18.39 \%)$, implement plans that has been made (34.76 $\%$ ) and evaluate $(\mathbf{4 2 . 2 0 \%})$; while $B$ category: define the problem $(46.35 \%)$, examine the problem $(33.89 \%)$, plan the solutions $(\mathbf{1 5 . 7 8 \%})$, implement plans that have been made $(\mathbf{2 0 \%})$ and evaluate $(33.33 \%)$. The lowest percentage in both categories is found in planning solutions and evaluating. Based on the results, the average problem solving ability in A category is $35.40 \%$, and $B$ category is $29.87 \%$. Based on the data, it can be concluded that students' problem solving abilities in A category and B category were still low. This ability can be improved by doing learning oriented to problem solving and familiarizing the students to solve problems in accordance with the stages of problem solving.
\end{abstract}

Keywords - problem solving ability, descriptive research, biology learning.

\section{INTRODUCTION}

Biology is a part of science which we usually call as natural sciences (IPA), that specifically studies about living things and the surrounding environment. This Biology lesson is very important because it is directly related to students as living beings themselves (humans). Biology is a subject that can be used or presented as a subject to apply the concept of problem solving.

Problem solving abilities are seen as a fundamental part of sains learning (Gok and Silay, 2010) [1]. A beginner (novice) sees the ability to solve problems as the ability to perform operational procedural or sequences of systematic actions, starting from realizing and understanding problems, planning solutions to problems, implementing plans, completing solutions, and evaluating the outcome of the problem (Wena 2012: 52) [2]. Paidi (2008: 4) explains that problem-solving ability is the ability that can eliminate the gap between circumstances and real [3]. According to Gagne in Widiyanti (2011: 2), high-level intellectual skills can be developed through problem solving [4]. This is similar to the students' high thinking skills, which will provide more effective problems solving (Ozden and Gultekir, 2008) [5]

Every students has the ability to solve problems that are different from one to another. This is appropriate with the statement Gok and Silay (2008) which state that the ability to solve problems is the ability of students to use the available information to determine what we are doing in a particular situation [6]. Problem solving ability refers to the effort needed by students in determining the solution for the problem they face (Selcuk et al, 2008) [7].

According to Carson (2007), the level of problem solving is divided into 5, they are: 1) Facing the problem (confront problem), that is feeling a difficulty. This process can include being aware of things that are not yet known in the ambiguity of a situation. 2) Defining the problem (define problem), that is clarifying the characteristics of the situation. This stage includes activities to identify what is known and unknown, find goals, and identify standard and extreme conditions. 3) Solution discovery (inventory several solutions), that is finding solutions. This stage can include activities that pay attention to patterns, identify steps in planning, and choose or find algorithms. 4) The consequences of the alleged solution, that is to do a plan based on the alleged solution, like using existing algorithms, collecting additional data, conducting needs analysis, reformulating the problem, trying for similar situations, and getting results (answers). 5) Test the consequences, that is testing whether the problem definition matches the situation or not. This stage can include evaluating process to know whether the hypothesis is appropriate or not, whether the data used is right or not, whether the analysis used is right or not, whether the analysis is suitable with the type or not, whether the results make sense or not, and whether the plan used can be applied to another problem or not[8]. 
TABLE 1. INDICATOR

\begin{tabular}{|c|c|c|}
\hline No & $\begin{array}{l}\begin{array}{l}\text { Problem solving } \\
\text { stages }\end{array} \\
\end{array}$ & Indicators \\
\hline 1. & $\begin{array}{l}\text { Identify the } \\
\text { problem }\end{array}$ & $\begin{array}{l}\text { - Determine the facts about the } \\
\text { problem } \\
\text { - } \text { Determine the concepts/categories }\end{array}$ \\
\hline 2. & $\begin{array}{l}\text { Examine } \\
\text { problem }\end{array}$ & $\begin{array}{l}\text { Identify the roots of the problem } \\
\text { - Check the reciprocal relationship } \\
\text { (cause and effect) }\end{array}$ \\
\hline 3. & Plan the solutions & $\begin{array}{l}\text { - Develop a problem solving plan } \\
\text { based on the root of the problem } \\
\text { Map the sub-problems and sub- } \\
\text { solutions }\end{array}$ \\
\hline 4. & $\begin{array}{l}\text { Implement the } \\
\text { plans which have } \\
\text { been made }\end{array}$ & $\begin{array}{l}\text { - } \begin{array}{l}\text { Make a sequence of problems to be } \\
\text { resolved } \\
\text { - } \\
\text { Sort the work steps related to the } \\
\text { solution that has been made }\end{array} \\
\end{array}$ \\
\hline 5. & Evaluate & $\begin{array}{l}\text { - } \begin{array}{l}\text { Check the feasibility of the solution } \\
\text { made }\end{array} \\
\text { Make assumptions regarding the } \\
\text { solutions made }\end{array}$ \\
\hline
\end{tabular}

However, this ability has not developed and is still categorized as low among high school students in Surakarta, especially in SMAN 8 Surakata. This is because students still cannot write and formulate problems that are relevant to the discourse that has been provided, students also have not been able to provide the best solutions related to the problems that have been formulated previously. Students' problem solving abilities that are still low need to be studied further. Based on observations through classroom observations and teacher and student interviews, it can be concluded that some of the causes of the low problem-solving ability of students are because of the more teacher-centered learning so that students are less active in learning, students have lack of interest in learning, and low ability of students to understand story exercises.

Based on the background of the importance of achieving problem solving skills in learning biology for high school students in Surakarta, especially SMAN 8 Surakarta, the authors carry out research that analyzes the problem solving abilities of high school students in biology learning.

\section{METHODS}

This research is descriptive research using a quantitative approach. The quantitative approach used in the study is analyzing which focuses on numeric data which is processed using statistical techniques (Sugiyono, 2015) [10]. This descriptive research uses instruments that are developed based on the stages of problem solving ability according to Mourtos et.al. which include identify problems, examine problems, plan solutions, implement plans that have been made, and evaluate (Moutos, et al, 2004) [11].

The population in this study were 108 students grade XI of SMAN in Surakarta, and the sample was 54 students which was categorized as A category (high class) and B category (low class). This selection was through purposive sampling technique and the data obtained was based on the analysis of the students' answers by coding each answer based on the rubric.
Calculation of the percentage of problem solving stage abilities scores are as follows:

percentage $=\frac{\text { score obtained }}{\text { maximum score }} \times 100 \%$

After obtaining the results of the percentage of problem solving capabilities, the students will be categorized according to table2:

TABLE 2. CATEGORIES OF PROBLEM SOLVING ABILITIES PERCENTAGE

\begin{tabular}{|l|l|}
\hline Percetage (\%) & Criteria \\
\hline $80-100$ & Very high \\
\hline $60-79$ & High \\
\hline $40-59$ & Fair \\
\hline $20-39$ & Low \\
\hline $0-19$ & Very low \\
\hline
\end{tabular}

\section{RESULT AND DISCUSSION}

\section{A. The Result of Reaserch}

The research data was obtained by giving a score of each indicator of problem solving abilty based on the Moutos that have been achieved. The relust are categorized as apercentage based of Surif. Comparison between scores obtained with the categories obtained will be shown in percentage from. The presentation will describe student's problem solving in biology learning.

a. The results of the study are based on the stages of problem solving abilities.

\section{TABLE 3. PRESENTATION RESULTS OF A CATEGORY CLASS}

\begin{tabular}{|l|l|l|}
\hline Percentage $(\%)$ & Problem Solving stages & Criteria \\
\hline 41.67 & Identify the problem & Fair \\
\hline 40 & Examine the problem & Fair \\
\hline 18.39 & Plan the solutions & Very low \\
\hline 34.76 & $\begin{array}{l}\text { Implement the plans which } \\
\text { have been made }\end{array}$ & Low \\
\hline 42.20 & Evaluate & Fair \\
\hline
\end{tabular}




\section{TABLE 4. PRESENTATION RESULTS OF B CATEGORY CLASS}

\begin{tabular}{|l|l|l|}
\hline Percentage $(\%)$ & Problem Solving stages & Criteria \\
\hline 46.35 & Identify the problem & Fair \\
\hline 33.89 & Examine the problem & Fair \\
\hline 15.78 & Plan the solutions & Very low \\
\hline 20 & $\begin{array}{l}\text { Implement the plans which } \\
\text { have been made }\end{array}$ & Low \\
\hline 33.33 & Evaluate & Low \\
\hline
\end{tabular}

\section{B. Discussion}

This study measures problem-solving abilities that refer to the theory of Mourtos et.al. which states that the stages in problem solving are divided into 5, they are identifying problems, examining problems, planning solutions, implementing solutions that are made and evaluating [12].

The results showed that of the 54 sample taken who worked on problem solving instruments, the average results were obtained that the problem solving ability of students in the State High School in Sukrakata was still low. This can be seen in Tables 3 and 4 which show that A category and B category have low ability in problem solving. This can be seen from the results that all students have not been able to master all stages of problem solving abilities yet. Based on the results of the research, the students' problem solving abilities varied on each of the stages, in this study, there were 5 stages.

In the first stage, that is identifying problems, A category was $41.67 \%$ and B category was $41.67 \%$. It means that some participants are sufficiently able to define the problem with fair criteria.

The second stage, checking the problem, category A category was $40 \%$ and B category was $33.89 \%$, it means that students are less able to examine the problem. At this stage, students are lack in determining reciprocal or causal relationships. Problem solving is influenced by several factors, one of the factors is positive ability that is directly related to the way of receiving, organizing, processing and describing the information received (Prmestasari, 2016) [13].

The third stage, that is planning solutions, A category got $18.39 \%$ and in the B category was $15.78 \%$, at this stage all students have not been able to form an action plan in accordance with the alternative solution chosen and think about the form of the plan so that can be implemented. The results of this study are inversely proportional to the research conducted by Eka Yulianti entitled "Analysis of Understanding Concepts and Biological Problem Solving Based on Critical Thinking Ability of Grade XI Students of Al-Azhar 3 High School Bandar Lampung", that the percentage of indicators for developing an action strategy was $84 \%$ [ 14]. Because on this indicator students have not been able to determine a good and appropriate strategy in implementing a solution.

The fourth stage, that is implementing the plan that has been made, A category was $34.76 \%$, and the B category was $20 \%$. At this stage, students are still unable to carry out the solutions that have been made well. The fifth stage evaluates that A category was $42.20 \%$ and B category was $33.33 \%$.

Only at the stage of identifying problems and evaluating which have fair criteria in mastering aspects experienced by students. This is because students are quite capable in determining relevant problems and capable in evaluating problems. Whereas in the aspect of planning a solution, the students have not been able to master the problem formulation. It is very important for every teacher to apply problem solving learning for their students. It is expected that students are trained to actively think, analyze, receive information, process data, and finally conclude. In line with the opinion of Iskandar (2017: 22), problem solving ability is very important to be applied in order to see how well the ability of students to think, analyze, and act to do solutions [15].

\section{CONCLUSION}

Based on the data, it can be concluded that students' problem solving abilities in both A category and B category were still low. This ability can be improved by doing learning oriented on problem solving and getting students to solve problems in accordance with the stages of problem solving.

\section{ACKNOWLEDGMENT}

Researchers would like to thank Mr. Prof.Dr. Ashadi and Mr. Puguh Karyanto, S.Si., M.Sc., Ph.D., who have given moral and material support, and all of my friends who always give endless encouragement and support.

\section{References}

[1]Carson, J. 2007. A Problem With Problem Solving:Teaching Thinking Without Teaching Knowledge. The Mathematics Educator.Vol.17,No.2, hal.7-14

[2]Gok, T.\&Silay,I. (2008). Effect of Problem Solving Strategy Teaching on the Problem Solving Attitude of Cooperating Learning Group in Physics Education. Journal of Theoryand Practice in Education,.

[3]Gok, T.\&Silay,I (.2010). The Effects of Problem Solving Strategies on Students' Achievement, Attitud and Motivation. Latin- American Journal of Physics Education, Vol. 4 No. 1.hal.7-21.

[4]Mourtos, N, J., Okatomo, Dejong, N.,\& Rhee, J.(2004).Defining, Teaching, and Assessing Problem Solving Skills. UICEE Annual Conference on Engineering Education, 95192-0087.hal.2.

[5]Ozden, M. \& Gueltekin, M. (2008). The Effect of BrainBased Learning on Academic Achievement and Retention of Knowledge in Science Course. Electronic Journal of Science Education, 12(1): 1-17.

[5]Selçuk,G.S., Çalışkan,S., \& Erol, M. (2008). The Effects of Problem Solving Instruction on Physics Achievement, Problem Solving Performance and Strategy Use. Latin 
American Journal of Physics Education.Vol 2.No. 3, hal.151-166.

[6] Iskandar,Andi.(2017).Pratical Problem Solving. Jakarta: PT Elex Media Komputindo

[7] Paidi. 2011. Model Pemecahan Masalah dalam Pembelajaran Biologi di SMA. Artikel Jurusan Pend. Biologi, FMIPA UNY.

[8]pramestasi. Anggun, Eka., Rahman,Abdur., \&Hidayanto.(2016). Kemampuan Pemecahan Masalah Siswa dalam Menelesaikan Masalah Open-ended ditinjau dari Gaya Kogniti reflektif dan Inpulsif. Artikel seminar PPG SM-3T

[9]Sugiyono.(2015). Metode Penelitian Administrasi. Bandung: Alfabeta.
[10]Surif,j., Ibrahim,N,H., \& Dalim, S.F.(2012). Conceptual and Procedural Knowledge in Prblrm Solving.Prosediasocialand Behavioral Sciences,56,416-425.

[11]Widiyanti, Teti. (2011). Pengaruh Gaya Belajar Terhadap Kemampuan Pemecahan Masalah Matematika. Skripsi FKIP Universitas Islam Negri Syarif Hidayatullah Jakarta.

[12] Wena, M. 2012. Strategi Pembelajaran Inovatif Kontemporer. Jakarta: PT Bumi Aksara.

[13]Yulianti, Eka. 2017. Analisis Pemahaman Konsep dan Pemecahan Masalah Biologi Berdasarkan Kemampuan Berpikir Kritis Siswa Kelas XI SMA Al-Azhar 3 Bandar Lampung. Skripsi Pendidikan Biologi Universitas Islam Negeri Raden Intan Lampung. 